\section{Incongruent dissolution following comminution in karstic carbonates: implications for speleothem trace elements}

\section{CHRISTOPHER T WOOD AND ADAM HARTLAND}

University of Waikato

Presenting Author: cwood@waikato.ac.nz

The dissolution of carbonate bedrock is a major source for hydrologically sensitive paleoclimate proxies, such as trace element ratios, in speleothems (e.g. stalagmites). Recently, investigations of prior calcite precipitation, water-rock interaction, and incongruent dissolution (ICD) have hypothesized that a characteristic range $(\sim 0.709-1.45)$ in the slope of speleothem $\ln (\mathrm{Mg} / \mathrm{Ca})$ vs. $\ln (\mathrm{Sr} / \mathrm{Ca})$ is indicative of specific hydrologically controlled processes[1,2]. However, no observational studies have thoroughly examined the effects of comminution-related ICD $\left(\mathrm{ICD}_{\mathrm{C}}\right)$ on cave-specific host rocks, leaving out a potentially significant, if short-lived[3], influence on drip water and speleothem chemistry. We have conducted controlled dissolution experiments of comminuted host rocks in a cave-analogue environment ("GeoMIC," University of Waikato) to better characterize $\mathrm{ICD}_{\mathrm{C}}$ effects on drip water trace elements.

Preliminary results from leaching experiments in GeoMIC displayed $\mathrm{ICD}_{\mathrm{C}}$ effects sensitive to the water/rock ratio and resultant $\%$ total dissolution, while the highest observed increase in $\mathrm{Mg} / \mathrm{Ca}\left(\sim 7.25^{*} \mathrm{Mg} / \mathrm{Ca}_{\text {HostRock }}\right)$ occurred when total dissolution was less than $\sim 0.48 \%$. Despite their potential brevity in a cave system, systematic $\mathrm{ICD}_{\mathrm{C}}$ effects could complicate hydrological interpretations in speleothem climate records, as the average slope in $\ln (\mathrm{Mg} / \mathrm{Ca})$ vs. $\ln (\mathrm{Sr} / \mathrm{Ca})$ leached from our various limestone host rocks $(\sim 0.89)$ is identical to that expected from prior calcite precipitation[1,2]. However, we observe a distinctly steeper $\operatorname{ICD}_{\mathrm{C}}$ slope $(\sim 2.37)$ in a dolomite sample. We discuss other possibilities for trace elements affected by $\mathrm{ICD}_{\mathrm{C}}$, including a cave-based proxy for past seismic activity or a measure of weathering rates in rapidly evolving or glaciated terrains[3].

[1]Sinclair, D. J. Two mathematical models of $\mathrm{Mg}$ and $\mathrm{Sr}$ partitioning into solution during incongruent calcite dissolution. Implications for dripwater and speleothem studies. Chem. Geol. 283, 119-133 (2011).

[2]Wassenburg, J. A. et al. Calcite $\mathrm{Mg}$ and $\mathrm{Sr}$ partition coefficients in cave environments: Implications for interpreting prior calcite precipitation in speleothems. Geochim. Cosmochim. Acta 269, 581-596 (2020).

[3]Fairchild, I.J. and Killawee, J.A. 1995. Selective leaching in glacierized terrains and implications for retention of primary chemical signals in carbonate rocks. In: Kharaka, Y.K. \& Chudaev, O.V. (editors) Water-Rock Interaction. Proceedings of the 8th International Symposium on Water-Rock Interaction WRI-8, Vladivostok, Russia, 15-19 August 1995. A.A. Balkema, Rotterdam, 79-82.

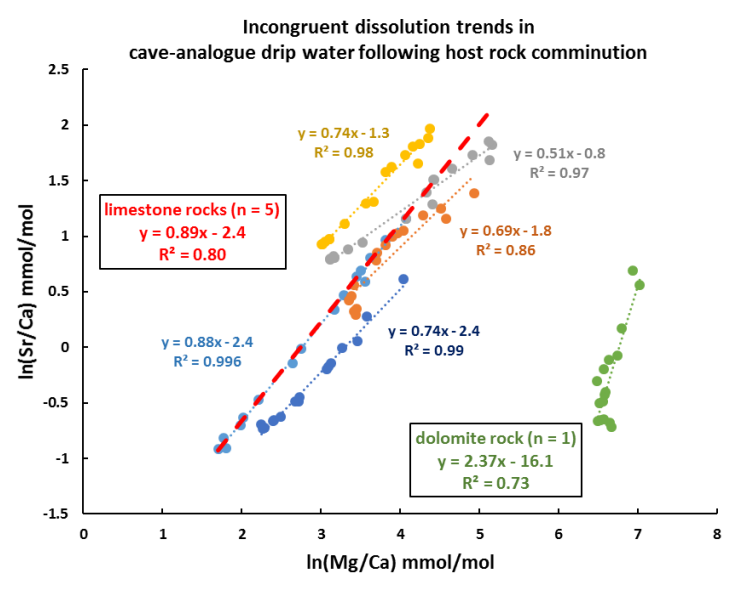

